\title{
Aplikasi Kasir Pada Adibah Boutique Berbasis Desktop
}

\author{
Zaid Romegar Mair \& Helen Yunita Sari \\ Program Studi Teknik Informatika Politeknik Sekayu \\ Email: romegardm@gmail.com
}

\begin{abstract}
Computers as human aids have advantages including speed, accuracy, and efficiency in data processing compared to manual systems. Computers have spread in various fields, both in the world of education and the world of work, including in the field of sales. Adibah Boutique has problems in terms of, among others, the irregularity of the management system, especially profit and loss, sales calculations (transaction activities), data collection of goods and preparation of sales reports still using manuals, cashier operators still use worksheet applications to complete each work activity, thus providing the impression of an impact that is less effective and efficient in terms of time and energy generated every day. Another problem in terms of the goods coding system and the absence of evidence between the seller and the buyer after the transaction raises a very basic problem, one solution is to use a desktop-based application that can manage sales information systems more easily thereby reducing the problems that occur in The Adibah Boutique. This application can be used as a commercial medium by the owner or staff of Adibah Boutique to make it easier to make sales transactions to consumers.
\end{abstract}

Keywords: Application, sales, Boutique.

\section{Pendahuluan}

Dari hari kehari kemajuan teknologi di bidang penjualan yang terus berkembang salah satunya adalah komputerisasi di bidang penjualan. Adibah Boutique mempunyai masalah dalam hal yaitu antara lain belum teraturnya sistem manajemen khususnya laba rugi, perhitungan masih menggunakan manual, masalah lainnya yaitu dalam sistem pengkodean barang dan bagaimana cara mengatasi sistem penjualan yang kurang dalam pengorganisasian penjualan dan kurang terstrukturnya sistem penjualan yang ada dalam Adibah Boutique, selain itu tidak adanya tanda bukti antara penjual dan pembeli setelah bertransaksi menimbulkan suatu permasalahan yang sangat mendasar, begitu pula yang terjadi dalam hal stok data barang dan juga dalam hal penyusunan laporan penjualan semuanya masih dilakukan dengan manual dalam proses penyelesainya.

Salah satu solusinya adalah dengan menggunakan aplikasi berbasis desktop yang dapat mengelola sistem informasi penjualan dangan lebih mudah Dengan demikian akan mengurangi permasalahan yang tejadi pada Adibah Boutique tersebut. Maka penulis tertarik meneliti "Aplikasi Kasir pada Adibah Boutique berbasis Desktop", yang dapat digunakan untuk pengelolahan data penjualan pada Adibah Boutique.

\section{Tinjauan Literatur}

\subsection{Aplikasi}

Asropudin (2013:6), Aplikasi adalah software yang dibuat oleh suatu perusahaan komputer untuk mengerjakan tugas - tugas tertentu.

Menurut Hengky W. Pramana (2012:17) “Aplikasi adalah satu unit perangkat lunak yang dibuat untuk melayani kebutuhan akan beberapa aktivitas seperti

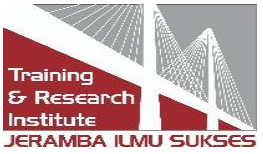


sistem perniagaan, game, pelayanan masyarakat, periklanan, atau semua proses yang hampir dilakukan manusia“.

Berdasarkan pengertian diatas maka dapat disimpulkan bahwa aplikasi adalah suatu perangkat lunak yang merupakan program dimana program tersebut dapat digunakan oleh pemakai untuk melaksanakan hal-hal yang bersifat umum serta untuk mengotomasikan tugas-tugas individual yang bersifat berulang (Antoni, Fikari \& Akbar, 2018; Antoni \& Akbar, 2019; Antoni, Jie \& Abareshi, 2020; Antoni, Herdiansyah, Akbar \& Sumitro, 2021).

\subsection{Boutique}

Menurut Arifah A. Riyanto (2003:120), Butik adalah suatu usaha pembuatan busana dengan jahitan kualitas tinggi dengan penjualan pelengkap busananya.

Berdasarkan pengertian diatas maka dapat disimpulkan bahwa butik adalah toko busana yang menjual busana kualitas tinggi dan juga menjual berbagai macam pelengkap busana.

\subsection{Database}

Menurut Abdulloh (2018:103), Database adalah kumpulan informasi yang disimpan dalam komputer secara sistematik sehingga dapat diperiksa menggunakan suatu program komputer untuk memperoleh informasi.

Menurut Agus Saputra (2011:1), Database merupakan suatu kumpulan data yang saling berhubungan dan berkaitan dengan subjek tertentu pada tujuan tertentu pula.

Berdasarkan pendapat para ahli maka penulis menyimpulkan bahwa database adalah sekumpulan data yang disimpan secara sehingga dapat diperiksa menggunakan suatu program komputer untuk memperoleh informasi.

\subsection{Microsoft Visual Studio 2010}

Menurut Ruli (2017:1), Microsoft Visual Studio adalah sebuah perangkat lunak lengkap yang dapat digunakan untuk melakukan pengembangan aplikasi, baik itu aplikasi bisnis, personal, ataupun komponen aplikasi lainnya dalam bentuk aplikasi console, aplikasi windows, ataupun aplikasi web.

Menurut (Fridayanthie wulansari, 2015) dalam Hidayatullah Visual Basic .NET adalah visual basic yang direkayasa kembali untuk digunakan pada platform .NET sehingga aplikasi yang dibuat menggunakan visual basic . NET dapat berjalan pada sistem komputer apapun, dan dapat mengambil data dari server dengan tipe apapun asalkan terinstal .Net .

Berdasakan penjelasan diatas penulis dapat menyimpulkan Microsoft Visual Studio 2010 adalah suatu aplikasi yang telah berkembang yag dapat digunakan pada platform .NET sehingga aplikasi yang menggunakan Visual Studio ini dapat berjalan di komputer apapun, dan dari server manapun dengan tipe apapun asalkan terinstal .NET.

\section{Metode Penelitian}

\subsection{Analisa Kebutuhan Proses}

\subsubsection{Kebutuhan Proses}

Kebutuhan Proses dari aplikasi ini adalah suatu tampilan dimana terdapat proses

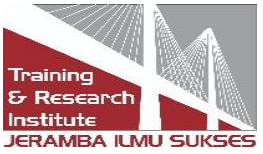


penambahan admin aplikasi, dan juga proses transaksi barang yang termasuk di dalamnya proses penambahan barang, hapus barang dan edit barang serta terdapat laporan penjualan harian, bulanan hingga tahunan.

\subsubsection{Kebutuhan Sumber Daya}

1) Kebutuhan Perangkat Keras (Hardware)

Perangkat keras yang digunakan dalam pembangunan aplikasi ini adalah laptop dengan spesifikasi sebagai berikut :

2) Perangkat Lunak (Software)

Perangkat lunak yang digunakan untuk membuat Aplikasi Penjualan Adibah Boutique adalah sebagai berikut :

a) Sistem Operasi

Sistem operasi yang digunakan untuk membuat Aplikasi Penjualan pada Adibah Boutique adalah Windows 10.

b) Visual Basic

Bahasa Pemrogramman yang digunakan dalam membuat aplikasi kasir Adibah Boutique ini adalah Visual Basic.

c) Microsoft Visual Studio

Aplikasi yang digunakan dalam membuat aplikasi kasir Adibah Boutique ini adalah Microsoft Visual Basic Studio 2010.

d) Database Server

Database Management System (DBMS) yang digunakan dalam pembangunan aplikasi ini yaitu Microsoft Access 2007.

\subsection{Perancangan Flowchart Diagram}

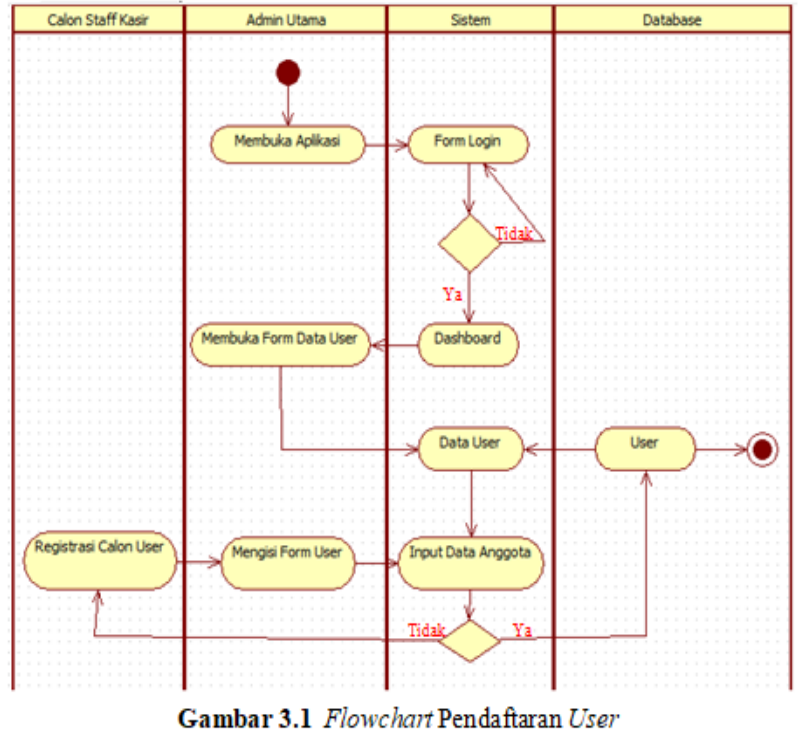

Gambar 3.1 Flowchart Pendaftaran User

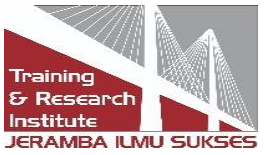




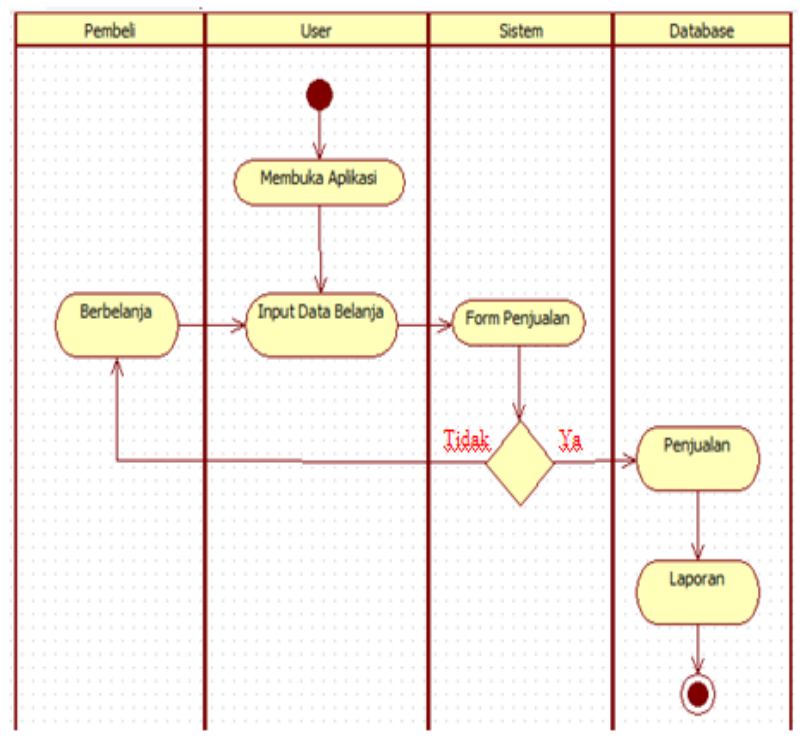

Gambar 3.2 Flowchart Transaksi Penjualan

Flowchart menggambarkan proses awal terjadinya input sampai keluarnya output. Dengan melihat diagram flowchart tersebut maka user dapat melihat proses awal hingga akhir dari aplikasi. Kendati begitu secara garis besar setiap perancangan flowchart selalu terdiri dari tiga bagian, yaitu input, proses dan output.

\subsection{Perancangan Diagram Konteks}

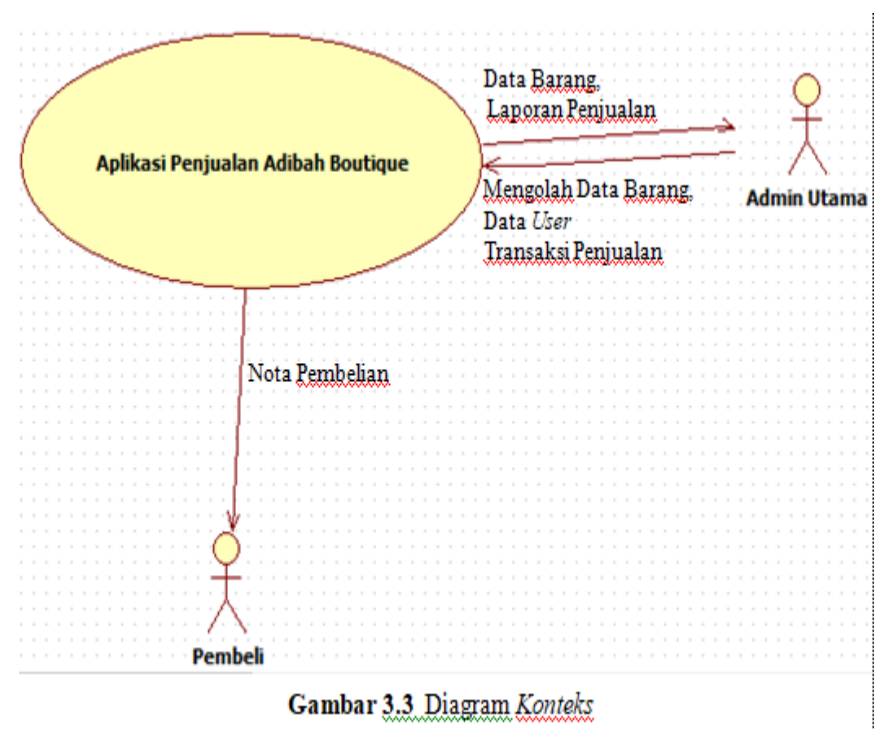

Diagram Konteks menggambarkan hubungan antara entity luar, masukan dan keluaran dari sistem. Diagram konteks direpresentasikan dengan lingkaran tunggal yang mewakili keseluruhan sistem

\subsection{Perancangan Data Flow Diagram Level 0}

Published by:

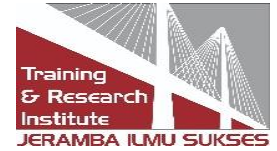




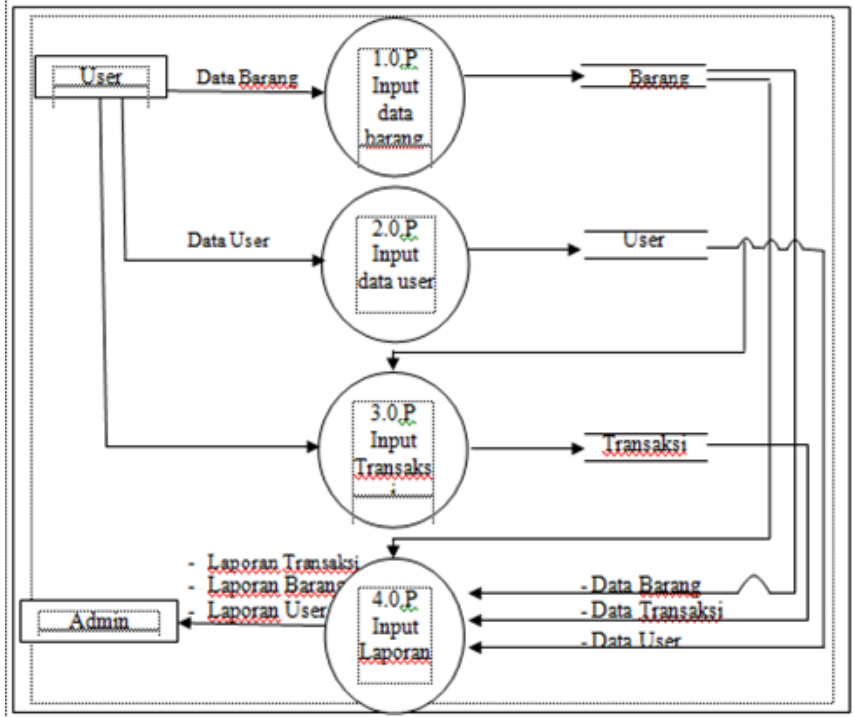

Gambar 3.4 Data Flow Diagram Level 0

DFD dapat digunakan untuk merepresentasikan sebuah sistem atau perangkat lunak pada beberapa level yang lebih detail untuk merepresentasikan aliran informasi atau fungsi yang lebih detail. DFD menyediakan mekanisme untuk pemodelan fungsional ataupun pemodelan aliran informasi.

\subsection{Perancangan ERD}

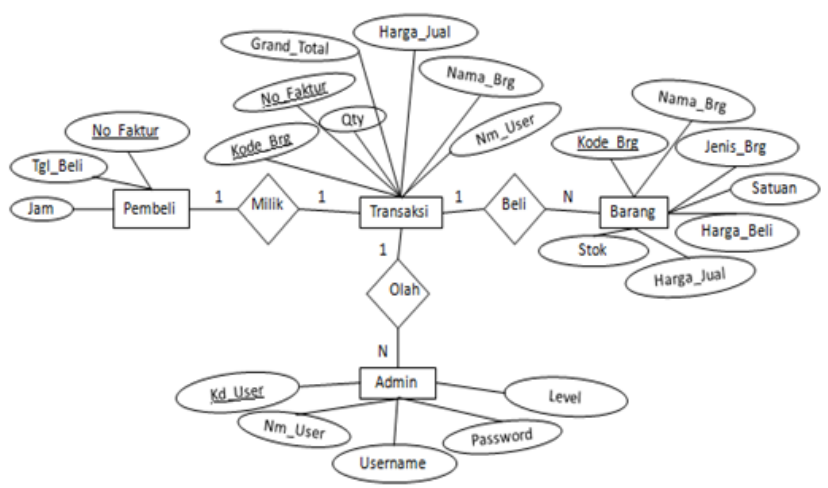

Gambar 3.5 Diagram ERD

ERD menggambarkan persepsi dari pemakai dan berisi objek-objek dasar yang disebut entitas dan hubungan antar entitas tersebut yang disebut relationship.

\subsection{Perancangan Tabel}

Nama tabel : tbl_barang

Primary key : kode_barang

Foreign key :-

Tabel 3.1 Tabel Barang 


\begin{tabular}{|l|c|c|l|}
\hline \multicolumn{1}{|c|}{ Nama field } & Tipe data & Ukuran & Keterangan \\
\hline kode barang & Text & 15 & Primary key \\
\hline nama barang & Text & 100 & \\
\hline jenis barang & Text & 25 & \\
\hline satuan & Text & 25 & \\
\hline harga beli & Long integer & & \\
\hline harga jual & Long integer & & \\
\hline stok & Integer & & \\
\hline
\end{tabular}

Nama tabel : tbl_jual

Primary key : faktur_jual

Foreign key :-

Tabel 3.2 Tabel Jual

\begin{tabular}{|l|c|c|c|}
\hline \multicolumn{1}{|c|}{ Nama field } & Tipe data & Ukuran & Keterangan \\
\hline faktur jual & Tetc & 15 & Primary key \\
\hline tanggal jual & Date/Time & & \\
\hline jam & Text & 15 & \\
\hline grand total & Long Integer & & \\
\hline dibayar & Long Integer & & \\
\hline kembalian & Long Integer & & \\
\hline
\end{tabular}

Nama tabel : tbl_rinci_jual

Primary key :-

Foreign key : faktur_jual dan kode_barang

Tabel 3.3 Tabel Rinci Jual

\begin{tabular}{|l|c|c|l|}
\hline Nama field & Tipe data & Ukuran & \multicolumn{1}{|c|}{ Keterangan } \\
\hline faktur jual & Text & 15 & Foreign key \\
\hline kode barang & Text & 15 & Foreign key \\
\hline qty & Int & 25 & \\
\hline total harga & Varchar & 50 & \\
\hline
\end{tabular}

Nama tabel : tbl user

Primary key : kode_user

Foreign key :-

Tabel 3.4 Tabel User 


\begin{tabular}{|l|c|c|c|}
\hline \multicolumn{1}{|c|}{ Nama field } & Tipe data & Ukuran & Keterangan \\
\hline kode user & Text & 5 & Primary key \\
\hline nama_user & Text & 30 & \\
\hline usemame & Text & 15 & \\
\hline password & Text & 15 & \\
\hline level & Text & 15 & \\
\hline
\end{tabular}

3.7 Perancangan Struktur Menu

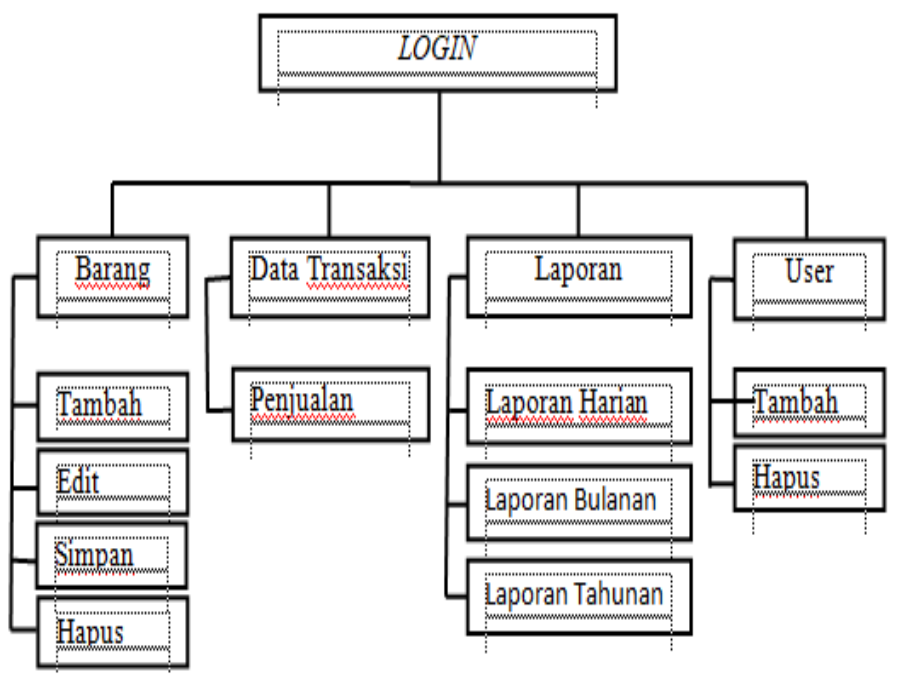

Gambar 3.6 Perancangan Struktur Menu Admin Utama

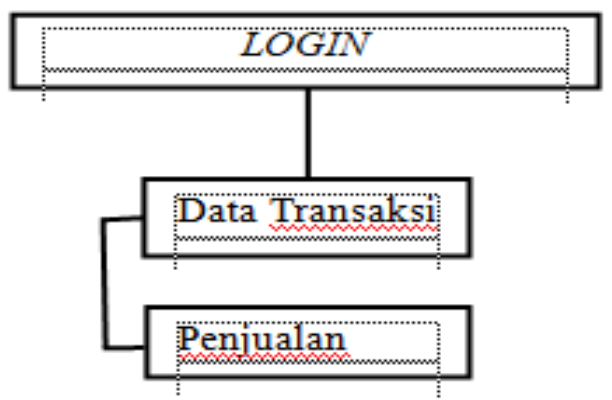

Gambar 3.7 Perancangan Struktur Menu Pegawai

\section{Hasil dan Pembahasan}

\subsection{Hasil}

Aplikasi ini dapat digunakan sebagai media perniagaan oleh owner ataupun staff Adibah Boutique untuk mempermudah dalam hal melakukan transaksi penjualan kepada konsumen.

Aplikasi ini dibuat dengan hak akses penuh bagi level admin (owner) dan hak akses terbatas bagi staff kasir Adibah Boutique, hal ini bertujuan untuk menjaga privasi dan keamanan data Adibah Boutique.

Published by:

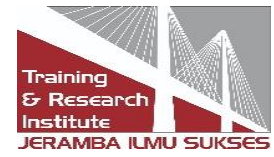




\subsection{Pembahasan}

Interface yang berhasil penulis buat pada setiap form adalah sebagai berikut :

\subsubsection{Halaman Login}

Halaman ini menampilkan form login, admin/staff kasir (yang selanjutnya akan disebut user) harus login terlebih dahulu untuk bisa menggunakan aplikasi. User harus memasukkan username dan password yang sesuai dengan data yang telah tersimpan di database.

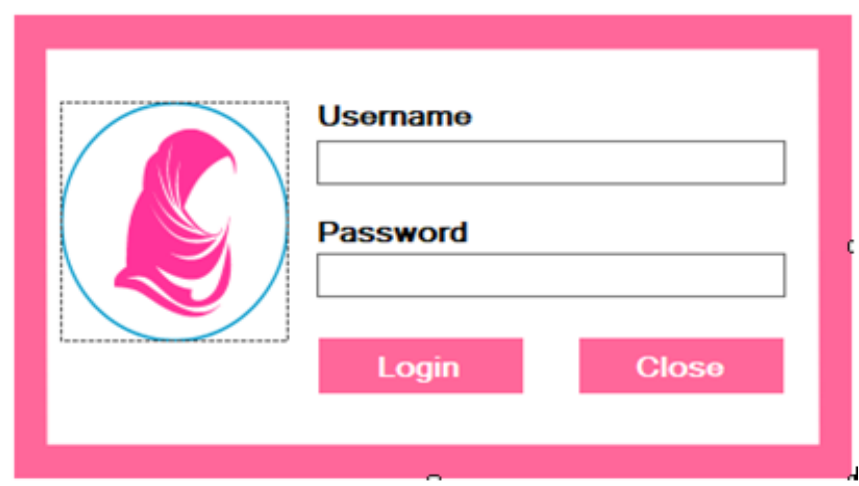

Gambar 4.1 Form Login

\subsubsection{Halaman Menu Utama}

Menu Utama menampilkan 4 pilihan tombol, yaitu tombol Barang untuk masuk ke menu barang, tombol Penjualan untuk masuk ke menu penjualan (melakukan transaksi), tombol Laporan untuk masuk ke menu laporan, dan tombol User untuk masuk ke menu user.

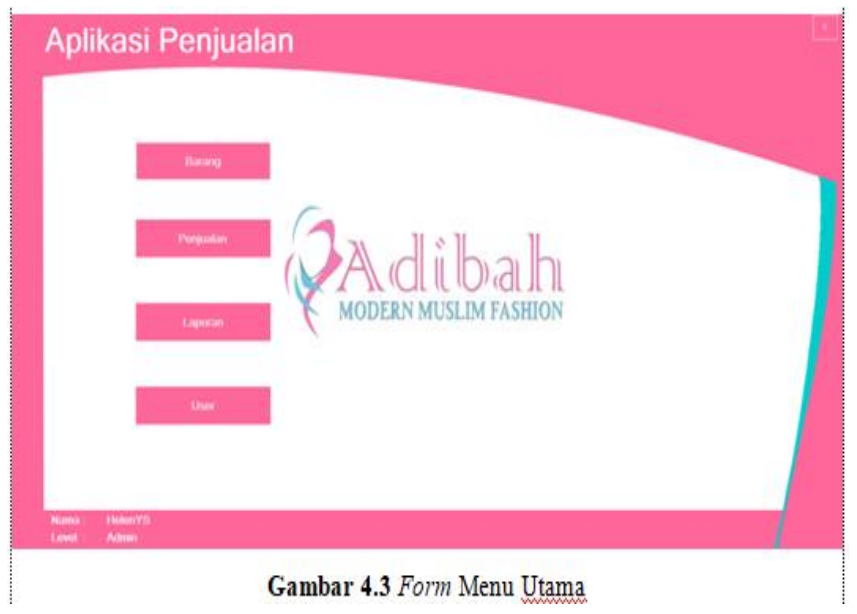

\subsubsection{Halaman Data Barang}

Pada Halaman Data Barang, menampilkan List Data Barang yang telah di tambahkan, juga terdapat tombol Tambah untuk menambahkan data barang dan terakhir ada textbox Pencarian Barang, pencarian data barang ini berdasarkan nama barang.

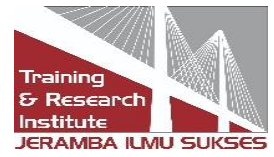




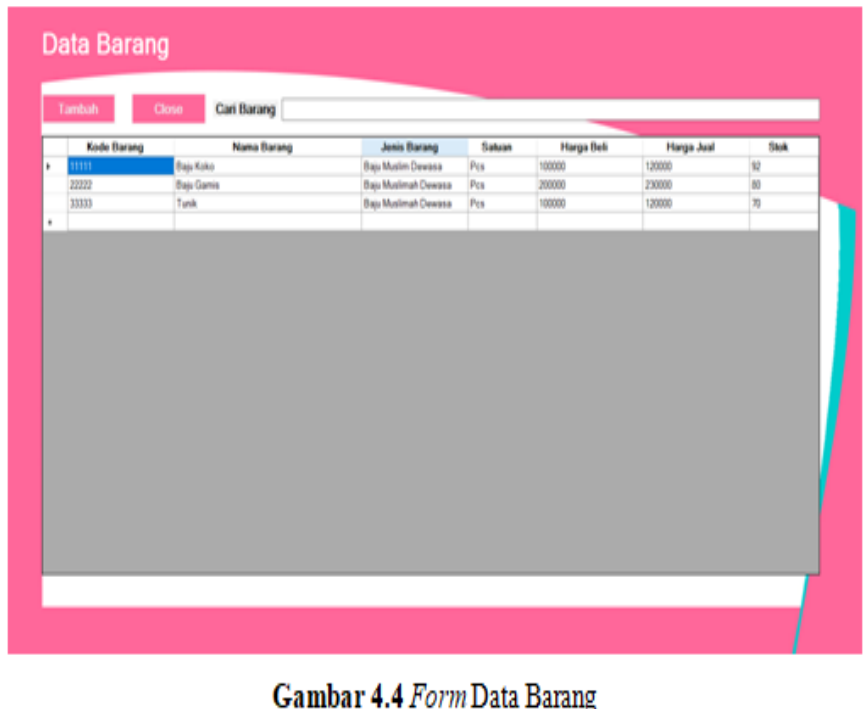

Berikut menu-menu yang terdapat dalam Form Input Barang ketika menekan tombol Tambah, yaitu:

a) Tombol Simpan

Jika pada beberapa inputan data belum diisi maka akan muncul peringatan "Data Harus Diisi Semua!!!", dan setelah semua inputan diisi kemudian menekan tombol Simpan maka "Data Berhasil Ditambahkan!!!"

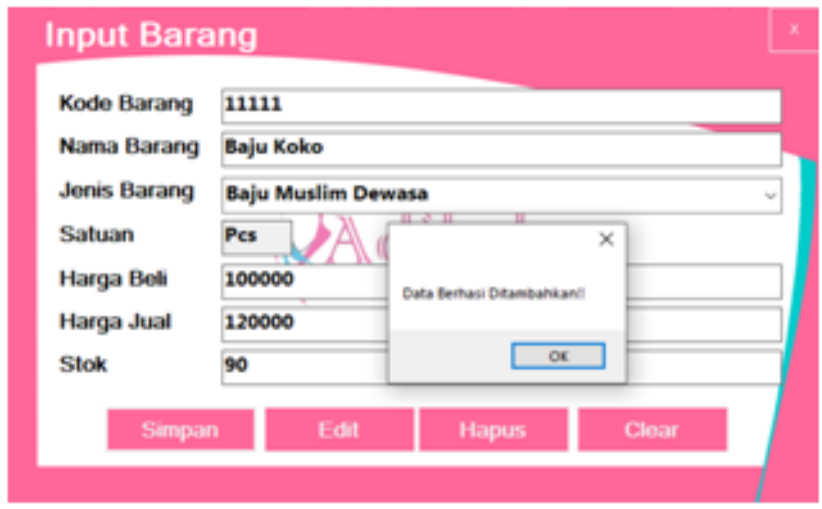

\section{Gambar 4.5 Form Input Barang Tombol Simpan}

b) Tombol Edit

Ketika data tampil semua, dengan memanggil berdasarkan kode barang, kemudian melakukan pengeditan sesuai data yang diinginkan setelah itu tekan tombol Edit maka "Data Berhasil Diedit!!!" 
Input Barang

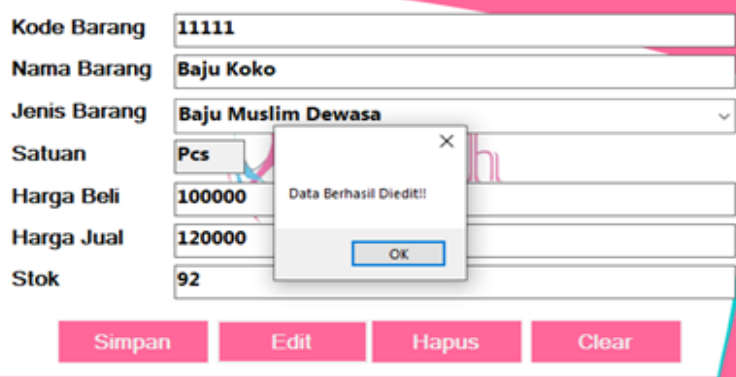

Gambar 4.6 Form Input Barang Tombol Edit

c) Tombol Hapus

Ketika data tampil semua, dengan memanggil berdasarkan kode barang, kemudian ketika menekan tombol Hapus kemudian muncul peringatan "Data Berhasil Dihapus!!!" maka data yang terpilih akan dihapus.

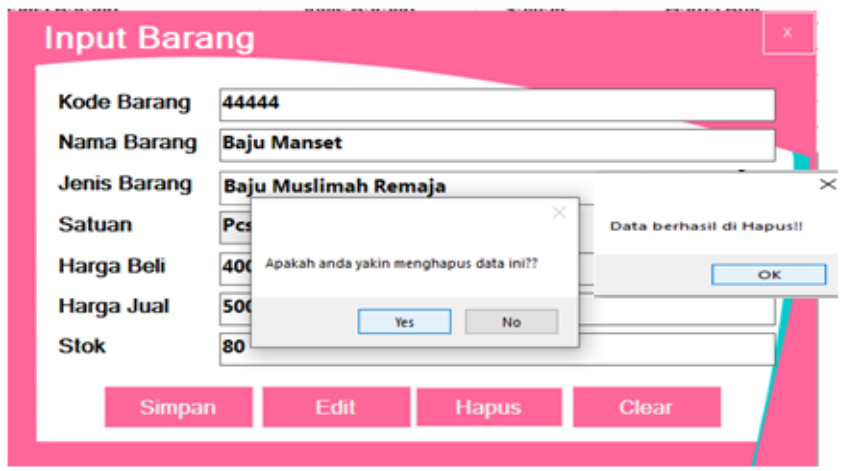

Gambar 4.7 Form Input Barang Tombol Hapus

d) Tombol Clear

Ketika data inputan telah diisi semua, kemudian tidak jadi menambahkan data maka dapat menekan tombol Clear untuk membersihkan data inputan.

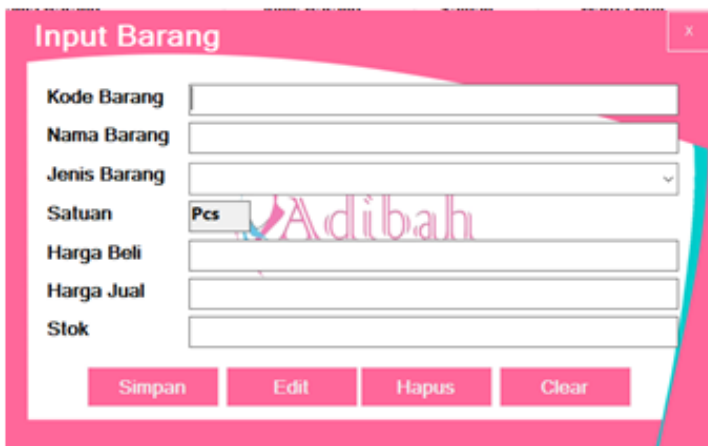

Gambar 4.8 Form Input Barang Tombol Clear

\subsubsection{Halaman Penjualan}

Published by:

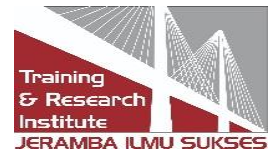


Pada Halaman Penjualan terdapat beberapa tampilan otomatis seperti No.Faktur, Jam, Tanggal dan Nama Kasir yang bertugas. Untuk memulai transaksi user langsung bisa mengetik kode barang pada textbox yang telah disediakan kemudian menekan enter dan langsung diarahkan ke textbox QTY yaitu menentukan berapa banyak item yang akan di beli kemudian menekan enter lagi untuk memasukkan belanjaan dalam list pembelian barang, begitu seterusnya sampai barang yang dibeli ter-list semua, kemudian pada Grand Total menampilkan jumlah uang yang harus dibayarkan sesuai dengan belanjaan, kemudian user memasukkan jumlah uang yang diberikan pembeli pada textbox Dibayar, kemudian menekan Simpan maka Uang kembalian akan tertera di textbox Kembalian dan list belanjaan akan masuk ke database. List barang belanjaan juga dapat dihapus jika transaksi penjualan diurungkan, atau ada barang yang tidak jadi dibeli, dengan cara menekan salah satu baris pada barang yang tidak jadi dibeli, kemudian menekan tombol ESC, maka secara otomatis barang terhapus. Kemudian terdapat tombol Close di samping tombol Simpan, untuk menyudahi kegiatan transaksi penjualan.

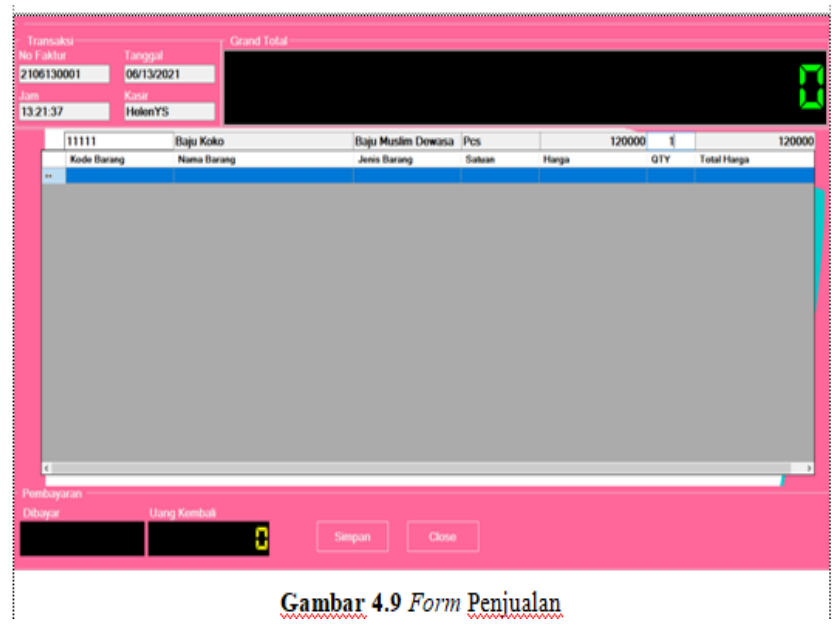

\subsubsection{Halaman Laporan}

Pada Halaman Laporan terdapat beberapan laporan yaitu Laporan Barang, Harian, Bulanan dan Tahunan. Jika kita menekan salah satu dari tombol, maka akan diarahkan sesuai dengan label tombol.

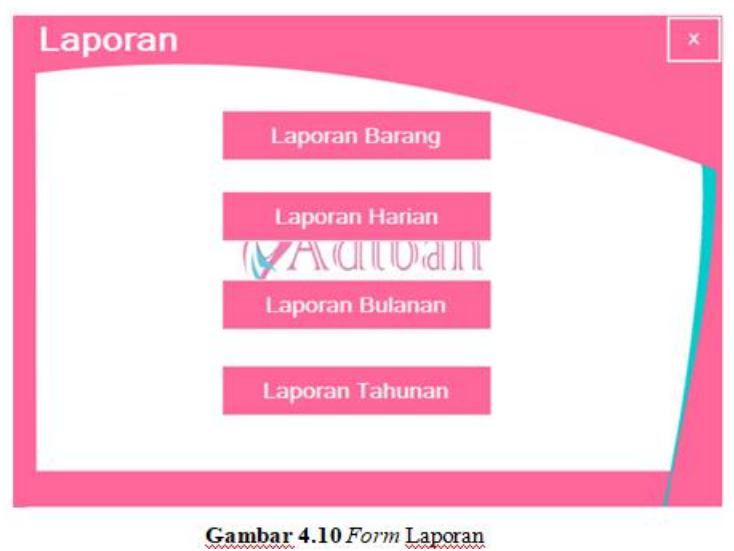

Berikut macam-macam bentuk laporan Barang Dan Penjualan :

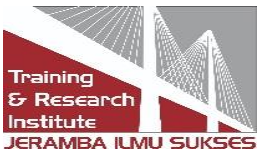




\section{a) Laporan Data Barang}

Pada Laporan Data Barang, terdapat 3 tombol yaitu View untuk menampilkan laporan data barang, kemudian Print untuk mencetak data barang yang telah ditampilkan, kemudian Export untuk memuat file data barang menjadi file external (tidak bergantung pada aplikasi) ke dalam beberapa format.

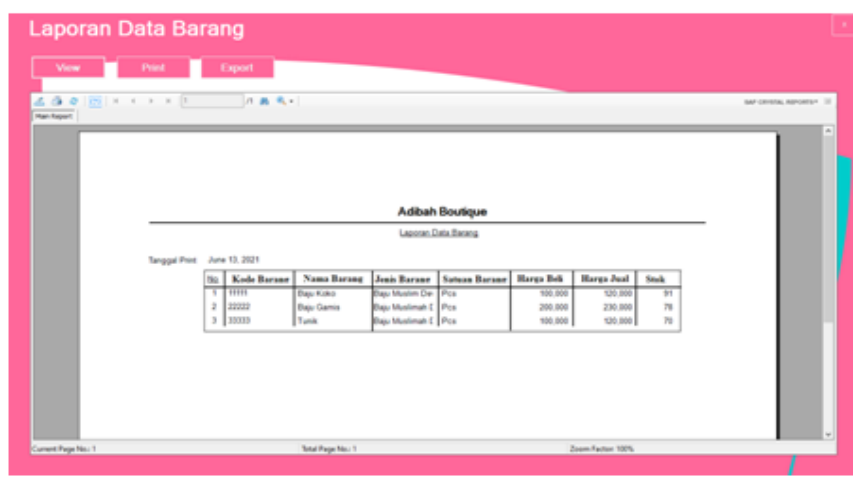

Gambar 4.11 Form Laporan Data Barang

b) Laporan Penjualan Harian

Laporan Penjualan Harian akan di buka (View), cetak (Print) dan dipindai (Export) sesuai waktu yang kita pilih.

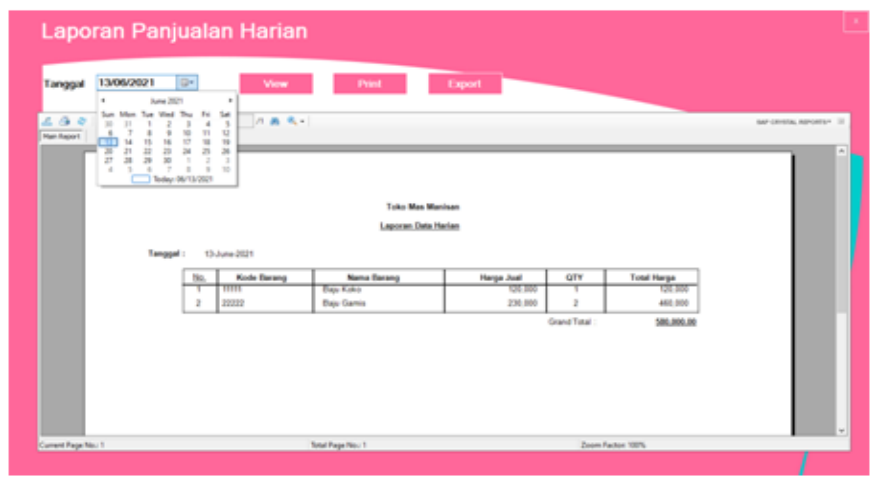

Gambar 4.12 Form Laporan Penjualan Harian

c) Laporan Penjualan Bulanan

Laporan Penjualan Bulanan akan di buka (View), cetak (Print) dan dipindai (Export) sesuai dengan Bulan dan Tahun yang kita pilih. 


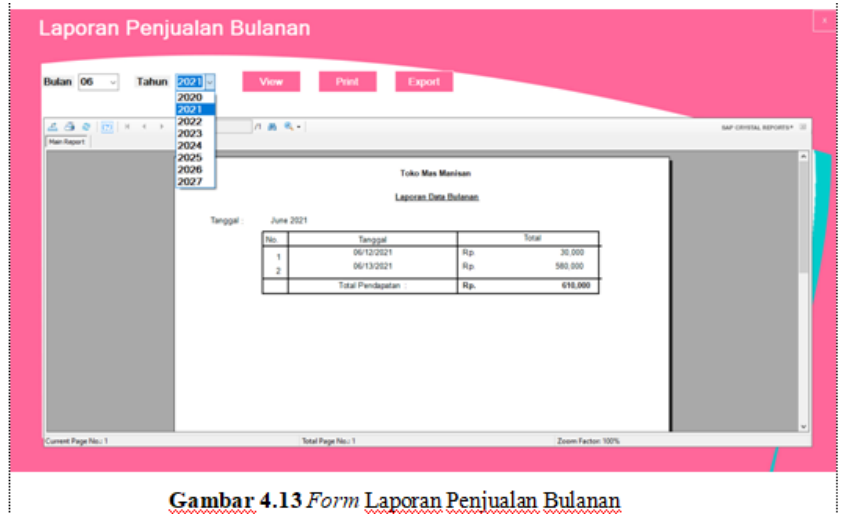

d) Laporan Penjualan Tahunan

Laporan Penjualan Tahunan akan di buka (View), cetak (Print) dan dipindai (Export) sesuai Tahun yang kita pilih.

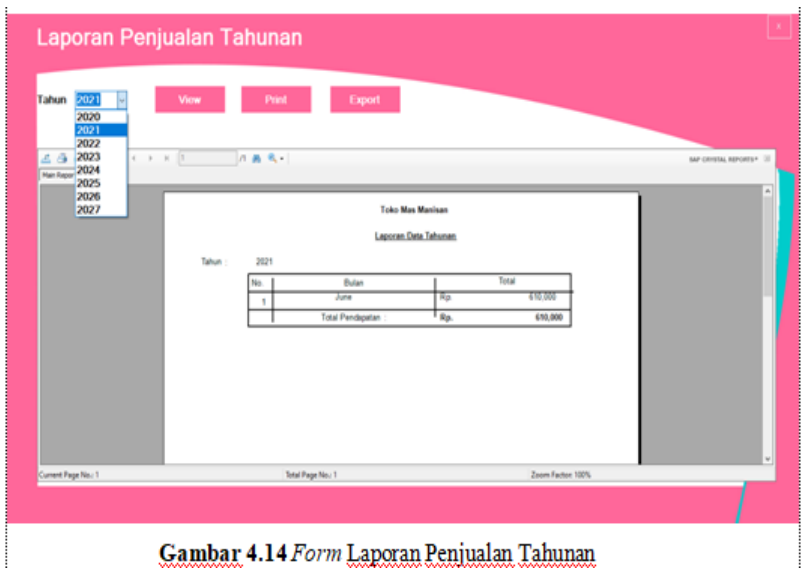

\subsubsection{Halaman User}

Terdapat beberapa pilihan tombol dalam form User, yaitu :

a) Tombol Simpan

Jika pada beberapa inputan data belum diisi maka akan muncul peringatan "Data Harus Diisi Semua!!!”, dan setelah semua inputan diisi kemudian menekan tombol Simpan maka "Data Berhasil Ditambahkan!!!" 


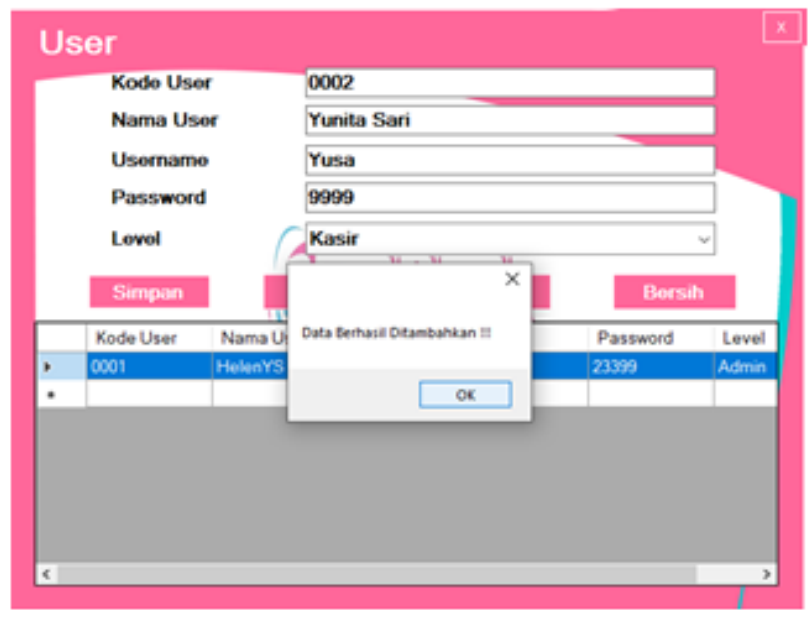

Gambar 4.15 Form User Tombol Simpan

b) Tombol Edit

Ketika data tampil semua, dengan memanggil berdasarkan kode barang, kemudian melakukan pengeditan sesuai data yang diinginkan setelah itu tekan tombol Edit maka "Data Berhasil Diedit!!!"

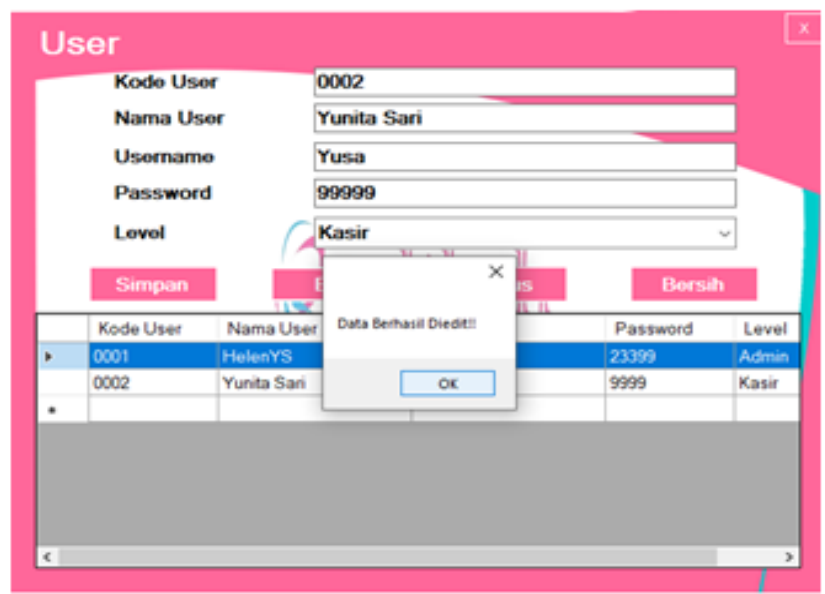

Gambar 4.16 Form User. Tombol Edit

c) Tombol Hapus

Ketika data tampil semua, dengan memanggil berdasarkan kode barang, kemudian ketika menekan tombol Hapus kemudian muncul peringatan "Data Berhasil Dihapus!!!” maka data yang terpilih akan dihapus. 


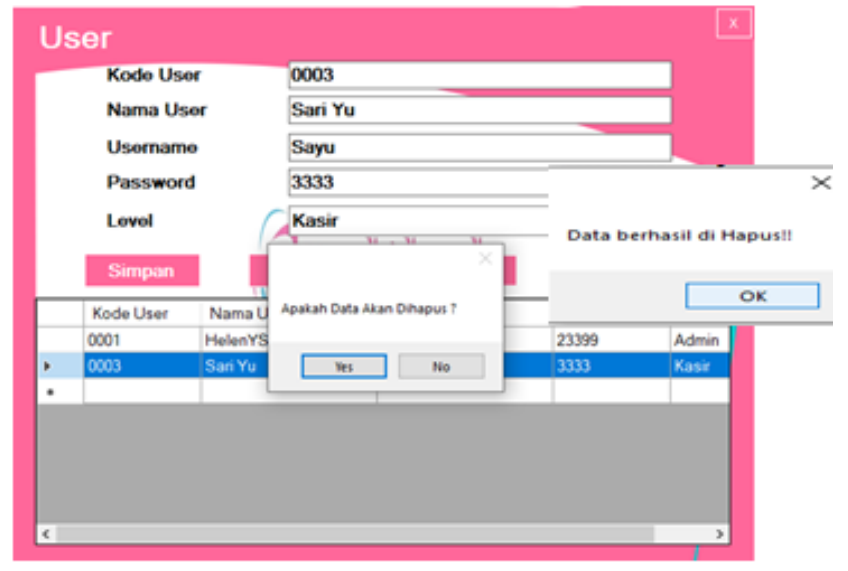

Gambar 4.17 Form User. Tombol Hapus

d) Tombol Bersih

Ketika data inputan telah diisi semua, kemudian tidak jadi menambahkan data maka dapat menekan tombol Bersih untuk membersihkan data inputan.

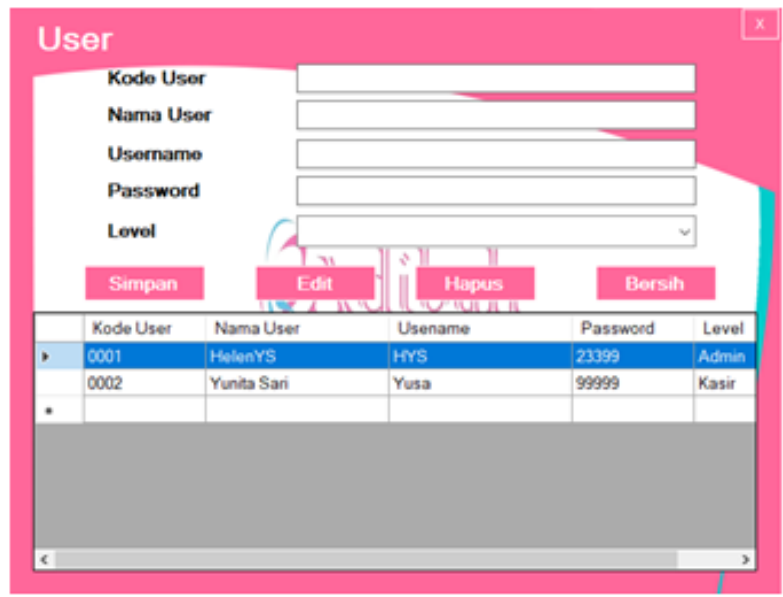

Gambar 4.18 Form User Tombol Bersih

\section{Kesimpulan}

Berdasarkan tahap demi tahap yang telah dilakukan dalam pembuatan aplikasi ini, maka penulis dapat menyimpulkan beberapa hal sebagai berikut:

1) Pembuatan aplikasi ini berhasil diselesaikan dengan metode pengembangan Waterfall, menggunakan bahasa pemrogramman visual basic dengan aplikasi yang digunakan Microsoft visual studio 2010, database yang digunakan Microsoft Access 2007 dan berhasil diuji menggunakan metode blackbox testing pada Adibah Boutique.

2) Aplikasi ini menampilkan data barang, transaksi penjualan, laporan dan data user.

\section{Referensi}

A.S., Rosa dan M. Shalahuddin. 2015. Rekayasa Perangkat Lunak Terstruktur dan Berorientasi Objek. Bandung: Informatika Bandung.

Abdulloh, Rohi. 2018. 7 in 1 Programmer Web untuk Pemula. Jakarta:PT. Elex Media

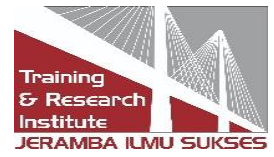


Komputindo.

Agus Saputra. (2011). Trik dan Solusi Jitu Pemrograman PHP. Jakarta:PT. Elex Media Komputindo.

Ahmad Rais Ruli. 2017. Jurnal Implementasi Aplikasi Pendaftaran dan Pembayaran Kontrakan Ahmad Rais Berbasis Desktop VB .NET dan Microsoft Access.

Antoni, D., \& Akbar, M. (2019). E-supply chain management value concept for the palm oil industry. Jurnal Sistem Informasi, 15(2), 15-29.

Antoni, D., Fikari, D., \& Akbar, M. (2018). The readiness of palm oil industry in enterprise resource planning. Telkomnika, 16(6), 2692-2702.

Antoni, D., Herdiansyah, M. I., Akbar, M., \& Sumitro, A. (2021). Pengembangan Infrastruktur Jaringan Untuk Meningkatkan Pelayanan Publik di Kota Palembang. JURNAL MEDIA INFORMATIKA BUDIDARMA, 5(4), 1652-1659.

Antoni, D., Jie, F., \& Abareshi, A. (2020). Critical factors in information technology capability for enhancing firm's environmental performance: case of Indonesian ICT sector. International Journal of Agile Systems and Management, 13(2), 159-181.

Arifah A. Riyanto. 2003. Desain Busana. Bandung: Yapemdo.

Asropudin, Pipin. 2013. Kamus Teknologi Informasi. Bandung: Titian Ilmu.

Darmawan, Deni., \& Kunkun Nur Fauzi. 2013. Sitem Informasi Manajemen. Bandung:PT Remaja Rosdakarya

Fauzi, F., Dencik, A. B., \& Asiati, D. I. (2019). Metodologi Penelitian untuk manajemen dan akuntansi. Jakarta: Salemba Empat.

Fridayanthie, Eka. Wida. 2015. Informatika, Jurnal Khatulistiwa Sistem, Perancangan Penjualan, Informasi Hiking, Peralatan Desktop, Berbasis Toko, Pada Outdoor, Cimone Eka, Tangerang Fridayanthie, Wulansari Studi, Program Informatika, Manajemen Tangerang, B S I Sutopo, Letnan Serpong, 3(2), 143-151.

Kadir, Abdul. 2017. Dasar Logika Pemrograman Komputer. Jakarta: Gramedia.

Muharto. Arisandy Ambarita. 2016. Metode Penelitian Sistem Informasi:Mengatasi Kesulitan Mahasiswa dalam Menyusun Proposal Penelitian.Yogyakarta: Deepublish.

Pramana, Henky W. 2012. Aplikasi Inventory Berbasis Access 2003. Jakarta:PT. Elex Media Komputindo.

\section{Copyrights}

Copyright for this article is retained by the author(s), with first publication rights granted to the journal.

This is an open-access article distributed under the terms and conditions of the Creative Commons Attribution license (http://creativecommons.org/licenses/by/4.0/)

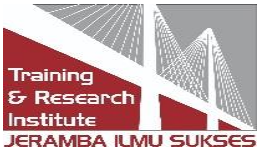

